\title{
EFFECT OF SPROUTING USING SALINE WATER ON STORAGE WHEAT GRAIN SPROUTS CHARACTER, PROXIMATE ANALYSIS AND PHYTOCHEMICAL COMPOUNDS FRACTION
}

\section{Basma M.M. Soliman¹, Nashwa A.I. Abu-El Azm¹, Elgammal' M.H. and Abdallah ${ }^{1}$ M.M.F.}

1- Horticulture Dept., Fac. of Agric., Ain Shams Univ., P.O Box 68, Hadayek Shubra 11241, Cairo. Egypt

2- Regional Central for Food and Feed, Agric. Res. Center. Giza, Egypt

*Corresponding author: youmamdouh@yahoo.com

Received 24 April, $2018 \quad$ Accepted 5 June, 2018

\section{ABSTRACT}

One day old wheat grain sprouts were used to study the effect of using saline water for sprouting on sprout characters, and changes of some chemical compounds after 2 years wheat grain storage of Gemmeiza 11 cultivar. Sprout characters showed no significant different in storage grain sprouts weight at all $\mathrm{NaCl}$ concentration while increased in fresh grains sprouts with increasing $\mathrm{NaCl}$ concentration. Sprouts chemical components as affected by storage revealed that storage Gemmiza II had the highest crude protein and the lowest carbohydrate content compared with dry fresh seeds. Non storage grains also had higher protein and lowest carbohydrate and energy content compare with dry fresh grains. The results of phytochemical analysis showed that wheat fresh grain sprouts increase phytochemical compounds and recorded the higher values when using saline water (37 compounds) followed by using tap water (33 compounds) compared with dry fresh grains (30 compounds). Saline water also enhanced the number of phytochemical compounds in two year storage grain sprouts (31 compounds vs. $28 \mathrm{com}$ pounds for tap water). Moreover, storage grains decreased the number of identified compounds during sprouting. It can be recommended that wheat grain sprouting is a procedure that has been developed to significantly increase the bioavailability of phytonutrients and phytochemical to ensure the nutritional security of population for Egypt.
Keywords: Storage wheat grain; Sprouting, Saline water, Proximate analysis, Phytochemicals

\section{INTRODUCTION}

Seeds commence deterioration upon separation from the mother plant. However, seed deterioration occurs during storage, leading to reduction of germination percent and decreasing seedling growth rate (Roberts 1983). Seed deterioration is greater under improper storage conditions, such as higher seed moisture and temperatures as in open storage.

The extract mechanism of seed deterioration is nuclear, however, different workers have suggested several possibilities. Roberts (1981) reported that some damages caused during storage are reversible under hydrated conditions, probably through the cellular repair mechanism. Vetucci (1992) noticed changes in lipid constituents of seeds in relation to loss of seed viability during storage.

Trawarth et al (1995) also suggested that lipid peroxidation and generation of free radicals contribute to seed deterioration. Beral-Luge and Leopold (1992) reported that soluble sugars are important components of deteriorating proteins and contribute to the deterioration changes occurring during seed storage. Soluble carbohydrates play an important role in desiccation tolerance and seed storability (Steadman et al 1996). However, ElEmam and El-Shaboury (2015) reported that protein and oil soybean seed content were not significantly affected by storage period and fatty acid increased. 
Naguib et al (2011) and Mersol et al (2006) reported highest significant crud protein and lowest carbohydrate content were observed in stored wheat and faba bean seeds respectively. Moreover, Mersal et al (2006) and El-Abady et al (2012) showed decreased in storage faba bean and soybean sprout characters, respectively. Similar effects on decreased wheat sprout characters was obtained by Mersal et al (2006), Jantana Yoja et al (2005) and Singh et al (2011).

However, Roberts (1981) reported that some damage during deterioration are reversible under hydrated condition and can undergo repair. Seed soaking in water for 2 to $5 \mathrm{~h}$ or in water-saturated atmosphere or $24 \mathrm{~h}$ followed by drying, resulted in higher seed viability and longevity

Seed germination and sprout growth are known to be more sensitive to salt stress compared with later development stages (Ashraf, 1994 and Yildirim et al 2002). However, salt stress stimulates the activity of antioxidant system (Rady, 2011 and Semida and Rady, 2014).

Wheat is an important crop for the Egyptian economy. During the past few decades research publications have encouraged increased consumption of whole grain food products due to their positive health benefits (Shahidi and Chandrasekara, 2013, Chanson-Ralle et al 2014 and Luthria et al 2015). The phytochemicals found in whole grains may be responsible for the health benefit of whole grains consumption as reported by Okarter et al (2010).

Since the quality and quantity of bioactive compound are important when the sprout are considered as a new functional food. The present study was undertaken to investigate the effect of sprouting using saline water on storage wheat grain sprout character, proximate composition and phytochemical compounds fraction.

\section{MATERIALS AND METHODS}

This study was carried out in Horticulture Department, Faculty of Agriculture, Ain Shams University during 2016-2017.

Wheat grains (Triticum sativum L.) Gemmeiza 11 cultivar fresh and 2 years old storage grains were obtained from the Crops Research Institute, Agriculture Research Center, Giza, Egypt. $\mathrm{NaCl}$ was obtained from El-Gomhoria Chemical Company, Cairo.

Sprouting of whole wheat grains (fresh or storage) was done in glass jar method as reported by
Abdallah (2008) using tap water and $\mathrm{NaCl}$ at 1000,2000 and 3000 ppm solution for grain soaking and sprouting. Wheat sprouts harvested one day old from grain soaking. The harvested grain sprouts were sun-air-dried according to Dzowla et al (1995) before grinding into fine flour.

Whole Gemmeiza 11 cultivar dry wheat fresh grain flour and both grain sprouts flour (using tap water or saline solution) samples were analyzed using GC/MS/MS for phytochemical analysis according to that reported by Tahany Aly (2015) and Ibrahim et al (2017b).

Data for sprout character were arranged in a completely randomized design with three replicates using ANOVA or reported by Snedecor and Cochran (1980). The treatment means were compared by using Duncan's Multiple Range Test and $5 \%$ level of significance as outlined by Waller and Duncan (1969).

\section{RESULTS AND DISCUSSION}

1. Effect of sprouting using saline water on sprout growth character

Data in Table (1) showed no significant different between tap water and $\mathrm{NaCl}$ concentrations (1000 to $3000 \mathrm{ppm}$ ) in storage sprout fresh and dry weight. However, the higher sprout fresh seeds sprouts were recorded in 2000 and 3000 ppm $\mathrm{NaCl}$. The longest radical length was observed in 2000 ppm NaCl for storage seed sprout and in tap water to $2000 \mathrm{ppm} \mathrm{NaCl}$ fresh seed sprout. While, the shortest sprout radical length was observed in $3000 \mathrm{ppm} \mathrm{NaCl}$. Similar results on the reduction effect of sprout radical length with higher $\mathrm{NaCl}$ concentration were reported by Cloulam \& Fares (2001), Ibrahim (2017a) and Abdel-Ghany (2017).

Since 2000 ppm NaCl recorded higher data than other concentration in most sprout characters, therefore, this concentration (2000 ppm NaCl) was selected for the following studies.

\section{Effect of sprouting on proximate composi-} tion of fresh and storage wheat seed sprout

Data in Table (2) showed that moisture content of storage wheat sprout were the lowest with tap water using for sprouting $(9.5 \%)$ compared with fresh seed sprouts (10.3-10.4\%), fresh dry seeds $(10.5 \%)$ and storage seeds using saline water for sprouting (10.5\%). However, the lower moisture 
Table 1. Effect of $\mathrm{NaCl}$ concentration in sprouting solution on one day old fresh and storage wheat seed sprout characters (Average of two experiments).

\begin{tabular}{|c|c|c|c|c|c|c|}
\hline \multirow{2}{*}{ NaCl concentration } & \multicolumn{2}{|c|}{$\begin{array}{c}\text { Sprout radical length } \\
(\mathbf{m m})\end{array}$} & \multicolumn{2}{c|}{$\begin{array}{c}\text { Sprout fresh weight } \\
(\mathbf{m g})\end{array}$} & \multicolumn{2}{c|}{$\begin{array}{c}\text { Sprout dry weight } \\
\text { (mg) }\end{array}$} \\
\cline { 2 - 7 } & $\begin{array}{c}\text { Fresh } \\
\text { seeds }\end{array}$ & $\begin{array}{c}\text { Storage } \\
\text { seeds }\end{array}$ & $\begin{array}{c}\text { Fresh } \\
\text { seeds }\end{array}$ & $\begin{array}{c}\text { Storage } \\
\text { seeds }\end{array}$ & $\begin{array}{c}\text { Fresh } \\
\text { seeds }\end{array}$ & $\begin{array}{c}\text { Storage } \\
\text { seeds }\end{array}$ \\
\hline Tap water & $8.2 \mathrm{a}$ & $7.0 \mathrm{~b}$ & $8.7 \mathrm{~b}$ & $8.7 \mathrm{a}$ & $52 \mathrm{~b}$ & $51 \mathrm{a}$ \\
$1000 \mathrm{ppm}$ & $7.8 \mathrm{a}$ & $7.0 \mathrm{~b}$ & $9.0 \mathrm{ab}$ & $89 \mathrm{a}$ & $53 \mathrm{~b}$ & $52 \mathrm{a}$ \\
$2000 \mathrm{ppm}$ & $7.8 \mathrm{a}$ & $8.7 \mathrm{a}$ & $9.2 \mathrm{a}$ & $87 \mathrm{a}$ & $55 \mathrm{a}$ & $51 \mathrm{a}$ \\
$3000 \mathrm{ppm}$ & $6.7 \mathrm{a}$ & $6.3 \mathrm{~b}$ & $801 \mathrm{ab}$ & $87 \mathrm{a}$ & $55 \mathrm{a}$ & $52 \mathrm{a}$ \\
\hline
\end{tabular}

Table 2. Effect of sprouting using saline water on the proximate analysis of the fresh and storage wheat grain sprout (g/100 g d.w) and energy (Kcal)

\begin{tabular}{|l|c|c|c|c|c|c|c|}
\hline \multicolumn{1}{|c|}{ Nutrients } & Moisture & Protein & Carbohydrates & lipids & Fiber & Ash & Energy \\
\hline Fresh seed sprout TW ${ }^{(1)}$ & 10.4 & 13.0 & 67.8 & 2.4 & 3.4 & 3.0 & 344.8 \\
Fresh seed sprout SW $^{(2)}$ & 10.3 & 13.5 & 67.5 & 2.5 & 3.5 & 2.7 & 346.5 \\
Storage seed sprout TW & 9.5 & 15.3 & 65.0 & 3.3 & 3.7 & 3.2 & 350.9 \\
Storage seed sprout SW & 10.5 & 15.4 & 67.0 & 2.1 & 3.3 & 1.7 & 348.5 \\
Dry fresh seeds & 10.5 & 12.4 & 71.2 & 1.9 & 2.5 & 1.5 & 351.5 \\
\hline
\end{tabular}

(1) $\mathrm{TW}=$ Tap water

(2) $\mathrm{SW}=$ Saline water $(\mathrm{NaCl} 2000 \mathrm{ppm})$

content in storage seed sprouts using tap water $(9.5 \%)$ showed increase in total lipid content (3.3\%) compared with other treatment. On the other hand using saline water for storage seed sprouting decreased the total lipid (2.1\%) close to fresh dry seed levels (1.9\%). These observation can be discussed by increment chemical compounds in storage seeds as fatty acids or compounds related to fatty acids as shown in phytochemical compounds Table (3). Moreover, using saline water for seed sprouting recovered the storage effect on lipids content in seed sprouts. The protein content of wheat dry fresh seed recorded the lowest value (12.4\%). Wheat sprouts recorded higher protein content than dry seeds. The storage seed sprouts recorded the highest protein content for both sprouts using tap water (15.3\%) and using saline water $(15.4 \%)$ followed by both sprouting of fresh seed $(13 \%$ and $13.5 \%)$ for using tap water and saline water, respectively. Sprouting increased protein content observation agreed with other finding before (Abdallah, 2008; Ibrahim 2017 and Abdel-Ghany, 2017).
All four samples obtained from wheat sprouts recorded an increase in total fiber and ash compared with dry seed flour sample. These results can be discussed by containing fibrous materials in the form of seed coat that is made up of cell wall polysaccharides such as cellulose and hemicellulose that are usually more resistant to degradation.

Regarding to total carbohydrates, data in Table (2) recorded decrease in wheat sprouts as compared with dry seeds. Data was were pronounced in storage seed sprouts (65 and 67\%) than non stored (fresh sprouts (67.8 and 67.5\%).

The energy values of wheat sprout samples were lower than those of raw dry seeds sample (Table 2). The higher sprout energy value recorded in the lowest moisture content and higher lipid content in addition to higher protein content (storage seed sprouting using tap water with close data to raw dry seed). 


\section{Effect of sprouting on phytochemical com- pounds of grains and sprouts}

Data in Table (3) showed 30 compounds were identified in the ethanol extract in whole wheat fresh dry grain flour sample but 33 compounds were identified in fresh wheat grain sprouts flour using tap water and these number decreased to 28 compounds in the storage wheat grain sprouts flour using tap water also. On the other hand 37 compounds, were identified in fresh wheat grain sprouts flour using saline water and these number decreased to 31 compounds in the storage wheat grain sprouts flour using saline water. These phytochemical compounds showed the presence of phenols, flavonoids, terpenoids, and other antioxidants (Table 3 ).

The total number of identified compounds data indicated that grain sprouting increased the number of compounds (33 to 37 compounds) compared with dry grains (30 compounds) and data was more pronounced when using saline water for sprouting (37 compounds) than using tap water (33 compounds). Saline water also enhanced the number of compounds in two year old storage grain sprouts ( 31 compounds vs 28 compounds for tap water). However, grain storage for two years decreased the number of identified compounds during sprouting.

Concerning the effect of storage grains on phytochemical compounds, data in Table (3) showed missed of (5) compounds which were Dodecanedioic acid; Gardenin, 6"-O-Malonyldaidzin, 2,6Dihydroxybenzoic acid and $\beta$-sitosterol, in wheat sprouts using tap water compared with nonstorage (fresh) grain sprouts using tap water also. Only one of these missed compounds (Gardenin) was detected in storage grain sprouts when using saline water and recorded the higher percentages area $(3.33 \%)$ compared with dry grain and other sprouts sample. However, there are two compounds missed which were, 9-cis-Retinoic acid and 5, 7-Dimethoxy-4-methylcoumarin in addition to Gardenin in storage wheat grain sprouts using tap water compared with fresh wheat dry grain sample and also detected in storage wheat grain sprout using saline water (Table 3).

Moreover, using saline water for fresh wheat grain sprouting detected (8) new compounds not available in dry fresh grain which were, Bovachinin; Dodecanedioic acid; Nobiletin; Erucic acid, (+)$\alpha$-Tocopherol; 6"-O-Malonyldaidzin; 2, 6Dihydroxybenzoic acid; and $\beta$-sitosterol.
There are two compounds in the flour of storage grain sprouts germinated in tap water were increased charbly in their percentage during sprouting. The $1^{\text {st }}$ one is 11,12 -Dihydroxy-5Z, $8 Z$, $14 Z$-eicosotrienoic acid which increased by about $93 \%$ and $95 \%$ higher than whole dry fresh grain flour and of fresh grain sprouts flour germinated in tap water respectively, the $2^{\text {nd }}$ compound is cis-13Eicosenoic acid which increased by about $93 \%$ and $89 \%$ compared with the same both flour respectively. Other compounds showed also increment but with less percentage are Oleic acid $(70 \%$ and $49 \%$ respectively); Linoleic acid ethyl ester (22\% and 63\% respectively); and Glycitin (19\% and $65 \%)$.

However, most of the increment chemical compounds in storage grains germinated in tap water are fatty acids or compounds related to fatty acids. These observation means quantitative changes in lipids accumulation has been taken place in seeds during storage. Wilson and McDonald (1992) reported that lipid peroxidation and subsequent peroxide accumulation, is a basic cause of deterioration and is one of the first changes in seed biochemistry detectable during storage.

On the other hand, opposite results obtained with four chemical compound in the flour of storage grain sprouts germinated in tap water which decreased charbley in their percentage during sprouting compared with whole dry fresh grain flour and of fresh grain sprout flour germinated in tap water. These compounds are 4',6-Dimethoxyiso flavone$7-0-\beta$-D-glucopyronoside $(-88 \%$ and $-93 \%$ decrement respectively); cis-9-hexodecenoic acid (-87\% and $-86 \%$, respectively), (E)-9-Octadecenoic acid ethyl ester (-61\% and $-30 \%$, respectively) and Biotin $(-25 \%$ and $-44 \%$, respectively) as shown in Table (3).

However, the increment or decrement of chemical compounds obtained in the flour of storage grain sprouts germinated in tap water showed opposite decrement and increment in the flour of storage grain sprouts germinated in saline water or, in the other meaning, saline water recovered the storage effect on grain sprouts and recommended to germinate storage wheat grains in saline water during sprouting.

There are other compounds with higher percentage in dry whole wheat grain flour, reduced in both tap water and saline water sprouts flour such as 2,5-Dimethoxy-2'-hydroxychalcone (from $6.19 \%$ to $0.72 \%$ and $1.75 \%$, respectively) and cis-9Hexadecenoic acid (from $17.11 \%$ to $15.4 \%$ and $9.46 \%$, respectively) (Table 3 ). 
Table 3. Effect of sprouting using saline water on the phytochemical compounds fractions of fresh and storage wheat grain

\begin{tabular}{|c|c|c|c|c|c|c|c|}
\hline \multirow[b]{2}{*}{ No. } & \multirow[b]{2}{*}{$\begin{array}{l}\text { R.T. } \\
\text { min. }\end{array}$} & \multirow[b]{2}{*}{ Name } & \multicolumn{5}{|c|}{ Area Sum\% } \\
\hline & & & $\begin{array}{l}\text { Fresh } \\
\text { seed } \\
\text { sprout } \\
\text { TW }\end{array}$ & $\begin{array}{l}\text { Fresh } \\
\text { seed } \\
\text { sprout } \\
\text { SW }\end{array}$ & $\begin{array}{c}\text { Storage } \\
\text { seed } \\
\text { sprout } \\
\text { TW }\end{array}$ & $\begin{array}{l}\text { Storage } \\
\text { seed } \\
\text { sprout } \\
\text { SW }\end{array}$ & $\begin{array}{c}\text { Dry } \\
\text { fresh } \\
\text { seeds }\end{array}$ \\
\hline 1 & 4.729 & 2,5-Dimethoxy-2'-hydroxychalcone & 0.72 & 1.75 & 1.46 & 3.92 & 6.19 \\
\hline 2 & 5.055 & Ethoxycitronellal & 0.83 & 0.84 & 0.60 & 1.54 & 0.86 \\
\hline 3 & 5.14 & $\begin{array}{l}\text { 3-(3,4-Dimethoxyphenyl)-4- } \\
\text { methylcoumarin }\end{array}$ & 0.32 & 0.70 & 0.52 & 1.68 & 1.04 \\
\hline 4 & 5.434 & 3,2',4',5'-Tetramethoxyflavone & 0.53 & 1.49 & 0.60 & 1.18 & 0.52 \\
\hline 5 & 5.837 & Dimethylfraxetin & 0.32 & 0.59 & 0.37 & 0.36 & 0.68 \\
\hline 6 & 6.159 & Astilbin & 0.44 & 0.59 & 0.48 & 0.53 & 0.66 \\
\hline 7 & 6.407 & 3,4,5-Trimethoxycinnamic acid & 0.39 & 0.33 & 0.39 & 0.43 & 0.46 \\
\hline 8 & 6.965 & Retinyl propionate & 0.31 & 0.73 & 1.29 & 0.41 & 0.63 \\
\hline 9 & 11.283 & L-(+)-Gulose & 0.95 & 1.70 & 0.41 & 2.31 & 1.61 \\
\hline 10 & 11.622 & Bavachinin & 0.67 & 1.109 & 0.65 & 1.00 & - \\
\hline 11 & 11.756 & (+)-a-Tocopherol & - & 0.97 & - & - & - \\
\hline 12 & 12.033 & Resodiacetophenone & 1.09 & 2.45 & 0.51 & 0.83 & 0.30 \\
\hline 13 & 12.485 & Dodecanedioic acid & 0.76 & 0.44 & - & - & - \\
\hline 14 & 12.856 & Nobiletin & - & 1.00 & - & - & - \\
\hline 15 & 13.989 & Erucic acid & - & 0.88 & - & - & - \\
\hline 16 & 14.278 & 6,4'-Dimethoxy-7-hydroxyisoflavone & 1.02 & 1.75 & 1.17 & 0.89 & 0.95 \\
\hline 17 & 14.4 & $\begin{array}{l}\text { 11,12-Dihydroxy-5Z,8Z,14Z- } \\
\text { eicosatrienoic acid }\end{array}$ & 0.82 & 1.95 & 16.45 & 1.48 & 1.16 \\
\hline 18 & 14.608 & $\begin{array}{l}\text { 4',6-Dimethoxyisoflavone-7-O- } \beta \text {-D- } \\
\text { glucopyranoside }\end{array}$ & 17.17 & 6.36 & 1.27 & 12.15 & 10.85 \\
\hline 19 & 14.804 & Glycitin & 0.79 & 1.59 & 2.25 & 1.74 & 1.83 \\
\hline 20 & 15.121 & 9,12-Octadecadienoic acid (Z,Z)- & 0.73 & 2.85 & 1.61 & 1.27 & 2.88 \\
\hline 21 & 15.166 & cis-13-Eicosenoic acid & 3.58 & 3.41 & 31.80 & 3.34 & 2.13 \\
\hline 22 & 15.524 & 9-cis-Retinoic acid & - & 3.24 & - & 2.63 & 1.61 \\
\hline 23 & 15.843 & Biotin & 30.92 & 15.99 & 17.27 & 27.48 & 23.16 \\
\hline 24 & 15.834 & cis-9-Hexadecenoic acid & 15.40 & 9.46 & 2.18 & 7.55 & 17.11 \\
\hline 25 & 15.989 & Linoleic acid ethyl ester & 1.50 & 2.08 & 4.01 & 1.99 & 3.11 \\
\hline 26 & 16.046 & (E)-9-Octadecenoic acid ethyl ester & 2.26 & 4.92 & 1.57 & 3.53 & 4.01 \\
\hline 27 & 16.25 & Isopropyl linoleate & 1.25 & 1.42 & 1.03 & 1.64 & 2.85 \\
\hline 28 & 16.763 & Oleic Acid & 1.24 & 2.39 & 2.43 & 1.73 & 0.73 \\
\hline 29 & 17.321 & Gardenin & 1.06 & 2.02 & - & 3.33 & 2.04 \\
\hline 30 & 17.676 & cis-10-Nonadecenoic acid & 1.67 & 2.35 & 1.96 & 2.88 & 2.03 \\
\hline 31 & 17.993 & cis-Vaccenic acid & 1.54 & 2.77 & 2.02 & 2.28 & 2.44 \\
\hline 32 & 18.344 & 5,7-Dimethoxy-4-methylcoumarin & - & - & - & 1.76 & 1.53 \\
\hline 33 & 19.529 & 6"-O-Malonyldaidzin & 2.40 & 4.71 & - & - & - \\
\hline 34 & 20.732 & Ricinoleic acid & 1.81 & 3.95 & 1.32 & 2.51 & 2.85 \\
\hline 35 & 21.44 & 2,6-Dihydroxybenzoic acid & 1.87 & 1.53 & - & - & - \\
\hline 36 & 21.84 & Linolein, 2-mono- & 2.16 & 4.62 & 2.78 & 3.24 & 2.28 \\
\hline 37 & 22.406 & Geranyl isovalerate & 1.29 & 2.24 & 1.62 & 3.24 & 1.54 \\
\hline 38 & 22.716 & $\beta$-Sitosterol & 2.16 & 2.85 & - & - & - \\
\hline
\end{tabular}


Regarding to terpenoids compound, Table (3) showed that whole wheat fresh grain sprouts using saline water for germination increased terpnoids values more than sprouts germinated tap water. The decrement of terpenoids compounds in tap water sprout flour sample can be explained by transferring some terpenoids to phenolics during sprouting period in tap water. Since terpenoids protect against increased membrane permeability. This may explain its increament in sprout flour sample of saline water than sprouts flour sample of tap water. It can be conclude that salt reduces the water potential of sprouting solution which prevents the supply of water by plants. The sprouts in salty sprouting solution receiving large amount of salt in radical cells and thus reduced the water potential, so it increase the absorption of water (Bojovic et al 2010), and protect against loss of terpenoids to sprouting solution which increased in sprout germinated in salinity compared with sprout germinated in tap water.

Different results of whole grain sprouts are relative to the different germination condition of using tap water and saline water as reported by Ibrahim et al (2017b). Dried sprout powder nowadays' can be used as wheat sprouts in wheat bakery flours to increase the nutritional value of the products without changing dietary behviour and to avoid risk of bacterial contamination in home grown and used fresh sprouts (Koehler et al 2007).

However, consumption of whole wheat grains and its derived food products provide a great source of bioactive phytochemicals that provide health benefit to human such as reduce the risk of type 2 diabetes, cardiovascular disease and cancer (Landberg et al 2014; Tucker et al 2014 and Seo et al 2015).

The results also indicated that the whole grain sprouts using tap water increased phenolic compounds as compared with whole wheat dry grains flour. Similar results was recorded by Ibrahim et al (2017). Moreover, the obtained results, suggested that germination is one of the most common and effective processes for increasing phenolic compounds and improving the quantity of wheat grains for exhibits therapeutic benefits. Similar results of increased phenolic components were obtained during germination of wheat (Ibrahim et al 2017b); oats (Xu et al 2009) and legumes (Khang et al 2016 and Ibrahim, 2017a).

Concerning terpenoids compounds results in Table (3) showed that using saline water for germination increased terpenponids values more than sprouts germinated using tap water. These decreament of terpenoids compounds in wheat sprouts using tap water compared with using saline water can explained by transferring some terpenoids to pheolics during sprouting period in tap water as reported before by Ibrahim, 2017.

Finally, from this study it can be recommended that grain sprouting is a procedure that has been developed to significantly increase the bioavailability of phytonutrients and phytochemical to ensure the nutritional security of population for Egypt.

\section{REFERENCES}

Abd Elghany T.S.A. 2017. Use of organic seed sprout to improve some bakery product. M.Sc. Thesis, Dept. of Env. and Bio-Agric., Fac. of Agric., Cairo, Al-Azhar Univ., Cairo, Egypt.

Abdallah M.M.F. 2008. Seed sprouts, a pharoh's heritage to improve food quality, Arab Univ. J. of Agric. Sci., 16(2), 469-478.

Ashraf, M. 1994. Breeding for salinity tolerance in plants. Critical Reviews in Plant Science. 13(1), 17-42.

Beral-Lugo I. and Leopold A.C. 1992. Changes in soluble carbohydrates during seed storage. PI. Physiol., 98, 1207-1210.

Bojovic B., Delic G., Topuzovic M. and Stankovic M. 2010. Effects of $\mathrm{NaCl}$ on seed germination in some species from families' brassicaceae and solanaceae. Kragujevac J. 32, 83-87.

Chanson-Rolle A., Lappi J., Meynier A., Poutanen K., Vinoy S. and Braesco V. 2014. Health benefits of whole-grain: A systematic review of the evidence to propose a dairy intake recommendation. The FASEB J., 28, 1117.

Choulam C. and Fares K. 2001. Effect of salinity on seed germination and early seedling growth of sugar beat (Beta vulgaris L.). Seed Sci., Technol., 29, 357-364.

Dzowela B.H., Hove L. and Mafongoya P.L. 1995. Effect of drying method on chemical composition and in vitro digestibility of multipurpose tree and shrub fodders. Tropical Grasslands. 29, 263-269.

El-Abady M.I., El-Emam A.A.M., Seadh S.E. and Yousof F.I. 2012. Soybean seed quality as affected by cultivars, threshing methods and storage periods. Res. J. of Seed Sci., 5(4), 115-125. 
El-Emam A.A.M. and Hoda El-Shaboury M.G. 2015. Soybean seed (Glycine max. (L) Merrill) Quality in relation to pod position and storage period. J. Plant Production, Mansoura Univ., 6(1), 99-108.

Ibrahim E.M.R. 2017a. Effect of sprouting using saline water on characters and chemical composition of sprouts of some legume and cereals seeds. Ph.D. Thesis, Fac. of Agric., Ain Shams Univ., Cairo, Egypt, 135 p.

Ibrahim E.M.R., Masoud M.S., El-Behairy U.A. and Abdallah M.M.F. 2017b. Effect of sprouting using saline water on phytochemical compounds of wheat grains and sprouting. J. Biol. Chem. Environ. Sci., 12(2), 1-8.

Jantana Y., Elha P. and Vearasilp S. 2005. Prediction of soybean seeds quality in relation to seed moisture content and storage. Conference on International Agricultural Research for Development. Stuttgart-Hohenheim, Germany, October, pp. 11-13.

Khang D.T., Dung T.N., Elzaawely A.A. and Xuan T.D. 2016. Phenolic profile and antioxidant activity of germination legume. Foods 5(2), 27 doi.lo.3390/Foods50027.

Koehler P., Hartmann G., Wieser H. and Rychlik M. 2017. Changes of folates, dietary fiber proteins in wheat as affected by germination. J. of Agric. and Food Chem., 55(12), 4678-4683.

Landerg R., Marklund M., Kamal-Eldin A. and Aman P. 2014. An update on alkylresorcinols occurrence, bioavailbility, bioactivity and utility as biomarkers. J. of Functional Foods. 7, 7789.

Luthria D.L., Lu Y. and Maria John K.M. 2015. Bioactive phytochemicals in wheat: Extraction, analysis, processing, and functional properties. J. of Functional Food, 18, 910-925.

Mersal L.F., Selim A.H. and El-Emam A.A. 2006. Effect of spraying insecticide treatments and storage period on quality of some faba bean (Vicia faba L.) seeds. Annals of Agric. Sci., Moshtohor, 44(2), 451-459.

Naguib N.A., Moamed E.A.O. and El-Aidy N.A. 2011. Effect of storage period and packaging material on wheat (Tricticum aestivum L.) and viability and quality. Egypt J. Agric. Res., 89(4), 1481-1497.

Okarter N., Liu C., Sorrells M.E. and Liu R.H. 2010. Phytochemical content and antioxidant activity of six diverse varieties of whole wheat. Food Chem., 119, 249-257.

Rady M.M. 2011. Effect of 24-epibrassinoillde on growth, yield, antioxidant system and cadmium content of bean (Phaseolus vulgaris L.). Plant under salinity and cadmium stree. Scientia Horticulturae, 129, 232-237.

Roberts E.H. 1983. Loss of seed viability during storage. Advances in Research and Technology of Seeds, 8, 9-34.

Roberts E.H. 1981. Physiology of aging and its application to drying and storage. Seed Sci. Technol., 9, 359-372.

Semida, W.M. and Rady, M.M. 2014. Presoaking application of propolisand maize grain extracts alleviates salinity stress common bean (Phaseolus vulgaris L.). Science Horticulturae, 168, 201-217.

Seo C., B. Yi, Oh S., Kwon S., Kim S., Song N., Cho J., Park K., Ahn J., Hong J., Kim M., Lee J. and Park K. 2015. Aqueous extracts of hulled barley containing coumaric acid and ferulic acid inhibit adipogenesis in vitro and obesity in vivo. J. of Functional Foods. 12, 208218.

Shahidi F. and Chandrasekara A. 2013. Millet grain phenolics and their role in disease risk reduction and health promotion: A Review. J. of Functional Foods. 5, 570-581.

Singh J., Srivastava Shikha S. Sinha A. and Bose B. 2011. Studies on seed Mycoflora of wheat (Triticum aestivum L.) treated with potassium nitrate and its effect on germination during storage. Research J. of Seed Sci., 4(3), 148-156.

Snedecor G.W. and Cochran W.G. 1980. Statistical methods. $7^{\text {th }}$ ed., lowa State Univ. Press, Ames lowa, USA, 507 p.

Steadman K.J., Pritchard H.W. and Dey P.M. 1996. Tissue specific soluble sugars in seeds an indicators of storage category. Ann. Bot., 77, 667-674.

Tahany Aly A.A. 2015. Biochemical studies of antidiabetic effect of some seed sprouts in adult male albino rats. Ph.D. Thesis, Department of Biochemistry, Fac. of Agric., Cairo Univ., Cairo, Egypt, 169 p.

Trawarth S.E., Tekrony D.M. and Hildebrand D.F. 1995. Soybean lipoxygenase mutants and seed longevity. Crop Sci., 35, 862-868.

Tucker A.J., Vandermey J.S., Robinson L.E., Graham T.E., Bakovic M. and Duncan A.M. 2014. Effect of breads of varying carbohydrate quality on post prandnial glycaemic, incettin and lipidaemic response after first and second meals in adults with diet controlled type-2 diabetes. J. of Functional Foods. 6, 116-125. 
Vertucci C.W. 1992. A colorimetric study of the changes in lipids during seed storage under dry conditions. Plant Physiol., 99, 310-316.

Waller R.A. and Duncan D.B. 1956. A Bayes rule for the symmetric multiple comparison problem. Amer. Statist. Ass. 64, 1484-1503.

Willson D.O. and McDonald M.B. 1992. Mechanical damage in bean (Phaseolus vulgaris L.) seed in mechanized and non-mechanized threshing systems. Seed Sci. Techno., 20, 571-582.
Xu J.G., Tian C.R. Hu Q.P., Luo J.Y., Wang X.D. and Tian X.D. 2009. Dynamic changes in phenolic compounds and antioxidant activity oats (Avena nuda L.) during steeping and germination. J. of Agric. and Food Chem., 57(21), 10392-10398.

Yildirim E., Dursun A., Guvenc I. and Kumlay A. 2002. The effects of different salt, bio stimulant and temperature levels on seed germination of some vegetable species. Acta Agrobotanica, $55,75-80$. 
مجلة اتحاد الجامعات العربية للعلوم الزراعية ، جامعة عين شمس ، القاهرة، مصر مجلد(26)، عدد(2D)، عدد خاص ، 2273-2265، 2019

Website: http://strategy-plan.asu.edu.eg/AUJASCI/

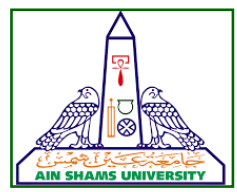

تأثير تنبيت حبوب القمح المخزنة بإستخدام الماء المملح على صفات النبت

وتحليل المكونات والمركبات النباتية الثانوية

[164]

بسمة محمد محمود سليمان $1{ }^{1}$ - نشوة عطية إبراهيم أبو العزم 1 - محمد حسانين الجمال2 -

ممدوح محمد فوزى عبد الله 1

1- قسم البساتين - كلية الزراعة - جامعة عبن شمس - ص.ب. 68 -حدائق شبرا 1142 - القاهرة - مصر

2- المركز الاقليمى للاغذية والاعلاف - مركز البحوث الزراعية - الجيزة - مصر

*Corresponding author: youmamdouh@yahoo.com

Received 24 April, 2018

Accepted 5 June, 2018

النباتية الثانوية وأوضحت نتائج التحليل الى أن حبوب

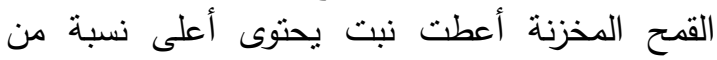

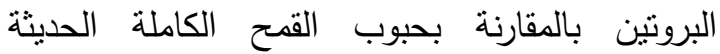

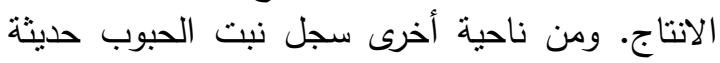

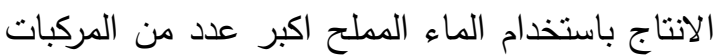

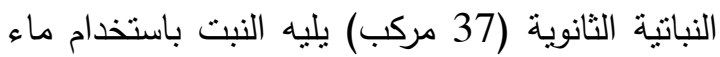

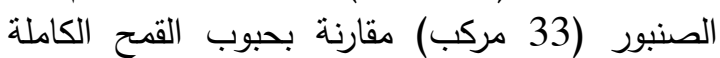

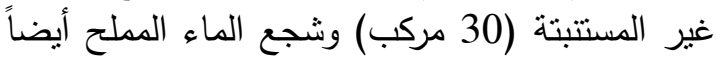

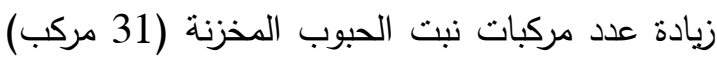
بالمقارنة بنبت ماء الصنبور (28 مركب) هذا وسجلت حبوب القمح المخزنة أقل عدد من المن المركبات اثناء عملية التتبيت.

وتعتبر عملية نتبيت حبوب القمح طريقة منطورة للزيادة المعنوية فى توفير المركبية حبربات الثنانوية والغذائية

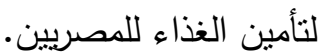

الكلمات الدالة: تخزين حبوب القمح، عملية التتبيت، الماء المالح، تحليل المكونات، المركبات الكيميائية الثانوية

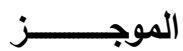

أجريت هذه الدراسة في معمل الزراعة العضوية بقسم البسانين - كلية الزراعة - جامعة عين شمس لترب حيث نم تتبيت حبوب القمح صنف جميزه 11 حديثة الزينة الانتاج (2016) مقارنة بالحبوب المخزونة منذ عامين باستخدام ماء الصنبور للمقارنة والماء المملح بكلوريد الصوديوم بتركيز المليون وذلك لمدة يوم واحد عقب فترة النقع لمدة 12

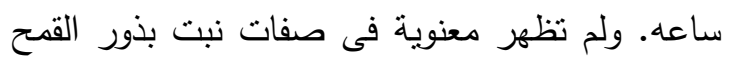

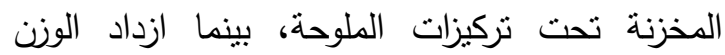
الطازج لنبت البذور حديثة الاتتاج بزيادة تركيز

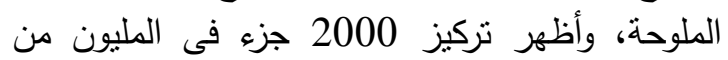

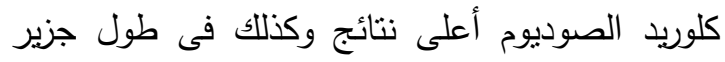
نبت القمح للبذور المخزنة. وتم تجفيف نبت حبوب القمح المخزنة والحديثة الناتجة من التتبيت باستخدام ماء الصنبور والماء

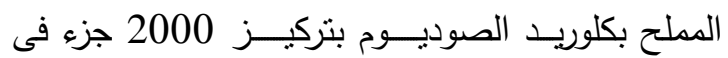
المليون وطحنها وكذلك حبوب القمح الكاملة حديثة الانتاج للمقارنة وأجريت تحليل المكونات والمركبات 

